\title{
Effect of pruning intensity on performance of apple cultivars in environmentally friendly production systems
}

\author{
Dremák P., Gonda I. \& Holb I. \\ Centre of Agricultural Sciences and Engineering, University of Debrecen, P.O.Box 36, H-4015 Debrecen, \\ e-mail:dremak@agr.unideb.hu
}

\begin{abstract}
Summary: The two worldwide accepted environmentally freindly production systems are integrated and organic. The two systems shows considerably differences in several practical production technology elements. These effects come forward in generative processes (e.g. flowering, fruit setting) and vegetative features (e.g. growth). The aim of our study was to study the effect of pruning intensity on growth features of cultivars in integrated and organic apple production. In early spring of 2009, we determined two pruning intensities (strong and week) on six scab resistant and tolerant cultivars. Strong pruning resulted in stronger shoot growth for all cultivars compared to weak pruning. It is obvious that pruning intensity had more effect on vegetative performance than conditional differences originates from integrated and organic production.
\end{abstract}

Key words: pruning intensity, integrated, organic, apple, tree growth

\section{Introduction}

Environmentally friendly production and protection systems are the only way of sustainable fruit production (Gonda, 2000). The two worldwide known envrinmentally friendly production systems are integrated and organic (Gonda, 2005; Holb, 2005). This two prodction systems have the same fundamentals; however, they show considerble differences in several practical aspects (e.g. for organic production, synthetic fertilizers are banned in nutrition supply and synthetic pesticides are banned in plant protection) (Anon, 1997; Holb, 2005). These differences result in different orchad management practices of the two production systems. Generative processes (e.g. flowering and setting) and vegetative processes (e.g. growth) show different characteristics in organic production compared to inegrated one which can be influenced greatly by the method and degree of phytotechnical operations (Gonda, 1979, 1993ab, 1995).

The aim of this study was to evaluate the effect of various methods and degrees of phytotechnical operations on growth features of apple cultivars in integrated and organic fruit production.

\section{Materials and methods}

In 2009, total numbers of flowers and fruit sets were observed on the first lateral twigs of seven trees for each cultivar.

Pruning was performed on five scab resistant cultivars in the spring of 2009. Two pruning intensity levels were performed as follows:
- Strong pruning: cut of several two years of twigs and cut of all one year-old shoots to half or two third of their total lenght.

- Weak pruning: only one year-old shoots were cut to half or two third of their total lenght.

After natural fruit drop (mid June), a moderate fruit thinning was perforemd mechanically especially in the organic production treatments. With this fruit thinning, similar fruit load was performed for both production treatments. Vegetative growth characteristics were observed at end August after bud closing stage.

ANOVA was performed to show statistical differences among pruning treatments.

\section{Results}

Growth was higher in the strong pruning treatments compared to weak one for all cultivars (Figure 1). Cultivar Rewena, Remo and Retina produced longer shoot growth in organic porduction compared to integrated one thogh the differences were not significantly different.

Management system has no clear effect on the total shoot productivity of apple cultivars (Figure 2). Shoot was longer for cultivars Pilot, Liberty and Reanda in the integrated production systems while it was shorter for cultivars Rewena, Remo and Retina for the organic production systems.

Strong pruning caused larger shoot growth compared to weak pruning for all cultivars (Figure 3). The smallest differences were obtained for cultivar Liberty while the largest one for cultivar Retina. In sum, intesity of pruning had larger effect on shoot growth compared to effect of management system on shoot growth (Figures 2 and 3). 


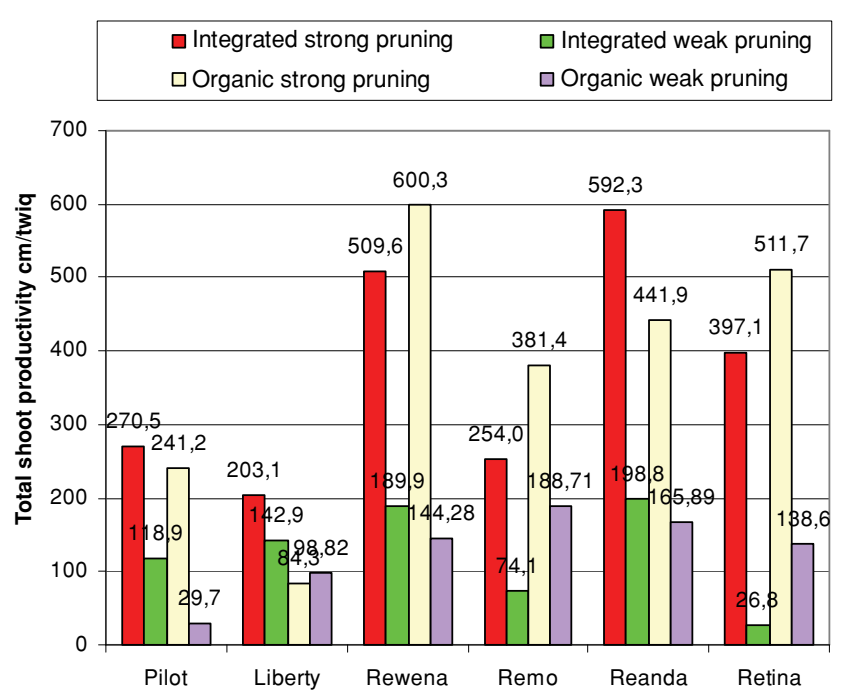

Figure 1. Effect of pruning degree and management system on total shoot productivity (Debrecen-Pallag, 2009)

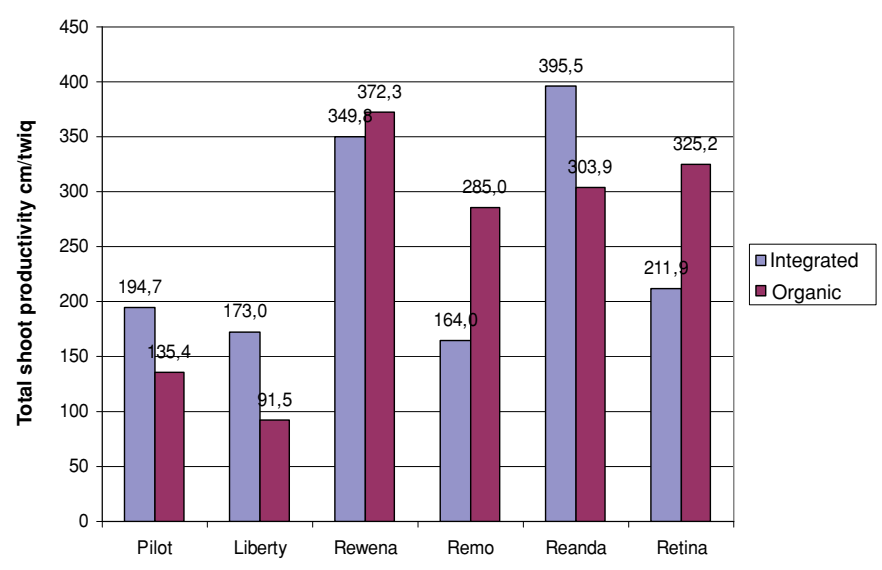

Figure 2. Effect of management system on total shoot productivity (Debrecen-Pallag, 2009)

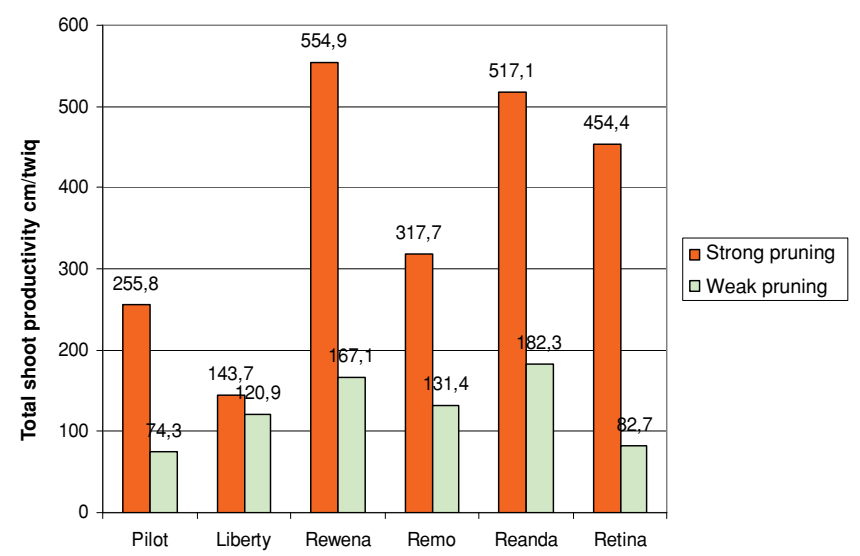

Figure 3. Effect of pruning dregree on total shoot productivity (Debrecen-Pallag, 2009)

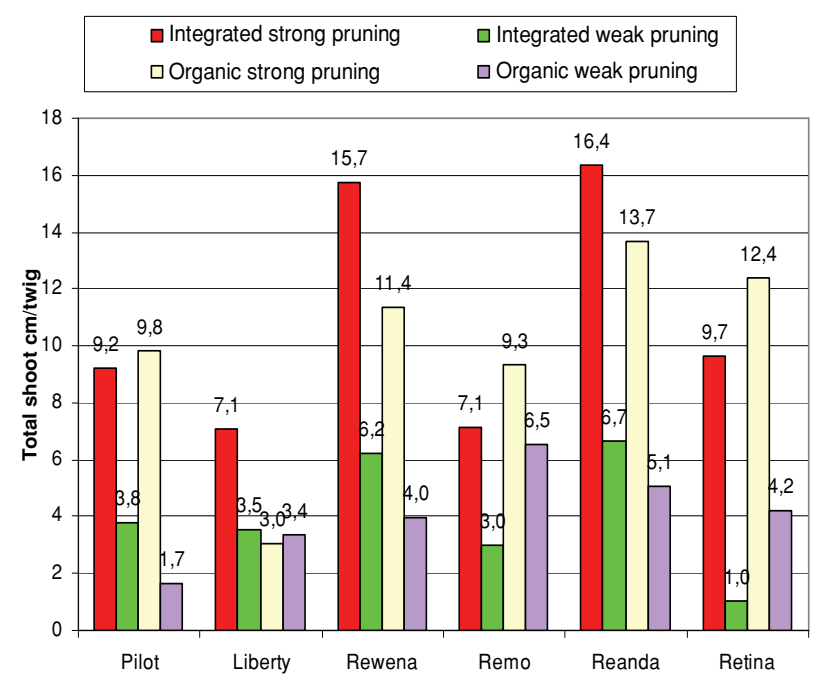

Figure 4. Effect of pruning degree and management system on total numbers of shoot (Debrecen-Pallag, 2009)

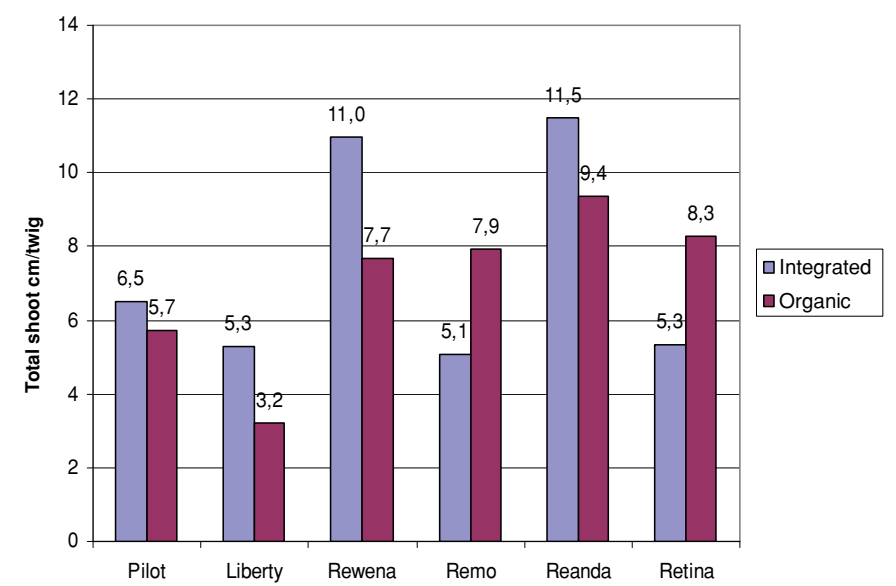

Figure 5. Effect of management system on total numbers of shoot (Debrecen-Pallag, 2009)

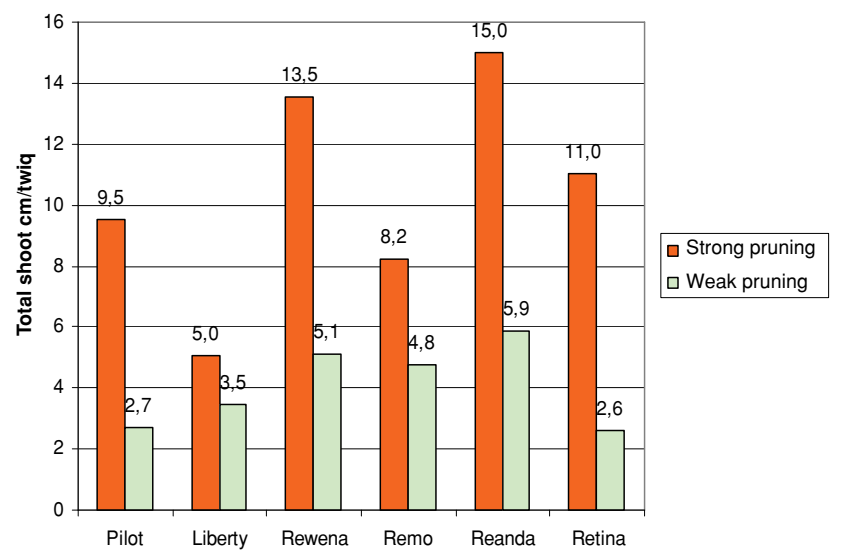

Figure 6. Effect of pruning degree on total numbers of shoot (Debrecen-Pallag, 2009) 
Strong pruning promoted more bud swelling compared to weak pruning for all cultivars (Figure 4). In the strong pruning treatment, cultivar Reanda produced the largest number of shoots while cultivar Liberty produced the least one.

The total numbers of shoot were higher in the integrated production system for cultivars Pilot, Liberty, Rewena and Reanda compared to organic production while cultivars Remo and Retina produced more shoots in organic production compared to integrated one (Figure 5).

Strong pruning caused larger shoot number compared to weak pruning for all cultivars (Figure 3). The smallest differences were obtained for cultivar Liberty while the largest one for cultivar Retina. In sum, intesity of pruning had larger effect on shoot number compared to effect of management system (Figures 2 and 3)

\section{Conclusions}

The effect of management system has low effect on shoot growth and number for the selected six apple cultivars. On the other hand, pruning had large effect on shoot growth and number for the selected six apple cultivars. Our results indicated that weak tree fitness can be compensated with stronger pruning treatments. This management practice can be used succesfully for organic production where tree fitness is lower compared to integrated one.

\section{References}

Gonda, I. (1979): A metszés időzítése, mértéke és a fák kondíciójának kölcsönhatásai. Újabb kutatási eredmények a gyümölcstermesztésben, 8: 21-28.

Gonda, I. (1993a): A fitotechnikai műveletek szerepe az alma integrált termesztéstechnológiájában. Integrált termesztés a kertészetben, (14): 72-78.

Gonda, I. (1993b): A metszés időpontjának, mértékének és módjának hatása két almafajta következő évi hajtásnövekedésére. Integrált gyümölcstermesztés. Évkönyv, 28. p.

Gonda, I. (1995): Kiút a válságból. Intenzív almatermesztés. PRIMOM Kiadó, Nyíregyháza

Gonda, I. (2000): Minőségi almatermesztés. PRIMOM Kiadó, Nyíregyháza

Gonda, I. (2005): Az ökológiai növényvédelem közvetett elemei. (In szerk. Holb I.: A gyümölcsösök és a szőlő ökológiai növényvédelme. 34-46. p.) Mezőgazda Kiadó. Budapest, 340 p.

Holb I. (2005): Az ökológiai (bio-) és az integrált termesztés és növényvédelem alapelvei és kapcsolatuk. Nemzetközi (IFOAM) növényvédelmi előírások. In: Holb I (szerk.) A gyümölcsösök és a szőlő ökológiai növényvédelme. Mezőgazda Kiadó, Budapest, pp. 11-17. 